\title{
特集解
}

\section{人工膝関節置換術におけるロボット技術 の適用*}

Application of the Robot Technology for Artificial Knee Joint Arthroplasty

\section{藏本孝一** 光石 衛*** 杉田直彦*** 井上貴之 ${ }^{* *}$ \\ Koichi KURAMOTO, Mamoru MITSUISHI, Naohiko SUGITA and Takayuki INOUE}

Key words robotic surgery, medical image, artificial knee joint arthroplasty

\section{1.は じめに}

医療現場において診断領域では CT P MRI といった高 度機器が使用されている一方で, 外科手術では医師の経験 や勘に依存しているのが現状である。近年, 患者のニーズ は多様化する傾向にあり, 身体機能の完全かつ早期回復が 強く望まれている。このようなニーズに対応するために は，より精密な手術が要求されることとなるが，人工関節 置換術等に代表される高度医療においては医師により高い 技量を要求することとなる.

したがって，コンピュータおよびロボット技術を導入し 手術支援を行うことで標準的な医師により高度医療におい ても高精度手術を実現することで, 患者が受ける医療の質 の向上が期待される。本稿では, 上記のような背景のも と, 人工膝関節置換術に対する手術ロボットの適用例につ いて述べる。

\section{2. 人工関節とその問題点}

人工関節置換術は, 関節リウマチや変形性関節症などに よる疼痛により関節機能が著しく低下した患者に対して施 される，特に，下肢関節疾患では，患者は歩行困難となり ADL (Activity of Daily Living)や QOL (Quality of Life)の 低下をもたらすため, その回復が強く望まれることとなる.

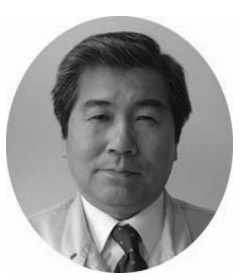

光石 衛

1986 年東京大学大学院工学系研究科機械工学専攻博士課程修了. 現在, 東 京大学大学院工学系研究科産業機械工学専攻教授.

杉田直彦

2005 年東京大学大学院工学系研究科産業機械工学専攻博士課程修了. 現在, 東京大学大学院工学系研究科産業機械工学専攻助手.

井上貴之

1998 年鳥取大学大学院工学研究科博士前記課程機械工学専攻卒. 現在, ナ カシマプロペラ株式会社ナカシマメディカル事業部開発グループ主任.
しかし，人工関節置換術は 60 歳代以降の患者に適用さ れる場合が多い，人工関節は体内で永久的に機能するわけ ではなく，耐用年数は平均で 10〜15 年といわれており， 日本人の平均寿命を考慮すれば, 一般的に困難を伴う再手 術を余儀なくされるためである。このため, 人工関節の耐 用年数の向上が大きな課題となっている.

人工関節の耐用年数を左右する主要因としては, (1)人工 関節の摺動面を構成する超高分子量ポリエチレンの磨耗に よる機能低下, (2)磨耗粉によって引き起こされる骨溶解 (Osteolysis) などによる骨と人工関節の固定性喪失が挙 げられる。 これらの問題を解決するアプローチとして, 高 耐久性 UHMWPE 摺動部材 ${ }^{1)}$, 人工関節の固定性を向上さ せるための生体活性材料 ${ }^{223)}$ などの材料学的見地からの研 究が行われている。一方で手術側に着目すれば, 正確な人 工関節の設置による構成部品の負荷軽減, 高精度骨切除に よる人工関節と骨の密着性向上による固定力の獲得を可能 にすることで, 人工関節の長寿命化が期待される. したが って, ロボットによる手術の高精度化が寄与する部分は大 きい.

\section{3. 手術ロボットの適用場面}

人工関節置換術は, 疼痛の軽減ならびに関節可動域を回 復させるため，損傷した関節表面を人工物で置換する手術 である。従来の一般的な手術では, 手術前に 2 方向から X 線レントゲンを撮影し, 荷重軸および骨軸を作図して 人工関節の設置位置，およびサイズの決定を行う.

医師は皮切後, 図 1 に示すようなカッティングガイド と呼ばれる特殊な治具を切除位置に固定し, 治具に設けら れたスリットに従いボーンソーにて骨切除を行う。ここで 治具の設置位置が重要であるが, 一般的に切除対象である 骨は皮膚や筋肉に覆われているため, 医師は限られた視覚 情報をもとに術前の X 線レントゲン画像と術中の患部を 照らし合わせながら位置を判断することになる。 また，ボ ーンソーと治具に設けられたスリット間のあそびや治具の ずれにより設置面加工精度が低下する ${ }^{4)}$ ため, その手術に は医師の経験と技量が頼りとなる。 


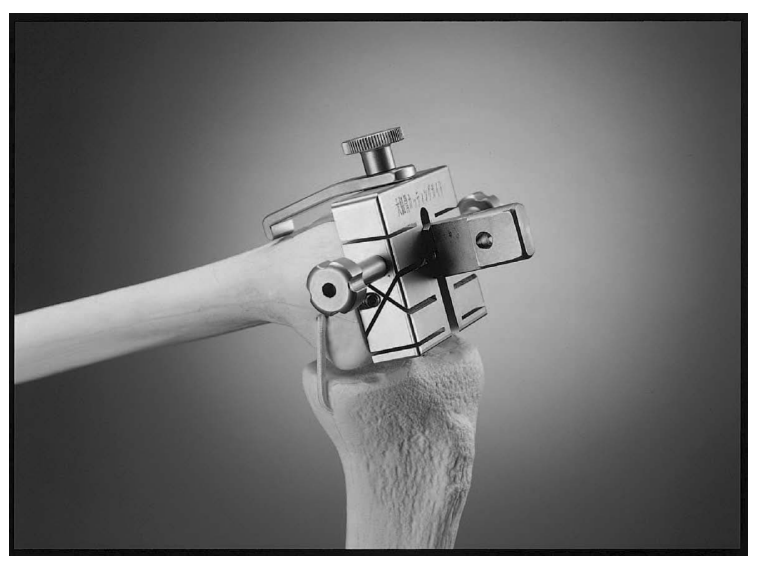

図 1 カッティングガイド

そこで，人工関節の耐用年数向上を目的として，手術口 ボットに正確な位置決め, 高精度な骨切除を分担させれ ば，高精度な手術を実現することができる。

\section{4. 手術ロボットに要求される事項}

整形外科分野では，人工股関節置換術を支援する ROBODOC ${ }^{5)}$ ，内視鏡下外科手術用システムとしては Intuitive Surgical 社の da Vinci ${ }^{6 / 7)}$, Computer Motion 社の ZEUS ${ }^{8}$ がある。これらの先行事例があるものの，幅広い 普及には至っていない，そこで，現在の臨床現場における 手術ロボット適用の際の問題点を明確化し，これらの事項 を総合的に考慮する必要がある。

(1）手術ロボットのコンパクト化

一般的な手術室は手術ロボットの設置を想定しておらず 既存ロボットシステムでは十分な作業空間が確保できな い.したがって，システム全体を小型化し室内で扱いやす くする必要があるとともに，X 線レントゲン撮影装置等 との併用が可能なロボット構成を考慮しなければならな い.

（2）安全性

ロボットアームとの接触，ロボットの動作による患者の 身体損傷を避けるため, 動きが予測しやすい軸構成が要求 される，また，従来の方法ではボーンソーによる骨切除の 際には補助者が脚を固定しているが，医師および補助者の 安全性も確保するため，患部を固定する治具が必要とな る。

(3) 清潔域の確保

患者の感染防止のため，清潔域/中間域/不潔域を明確に 区別し，エンドエフェクタ近傍を清潔域とし，滅菌・洗浄 を可能とする。

（4）容易な手術進行

産業機械分野では，数值情報によりロボットを制御する 場合が一般的であるが，医療分野では医師による容易な手 術進行拉よびオペレートを支援する情報提示，ユーザイン タフェースを検討する必要がある。

（5）手術時間

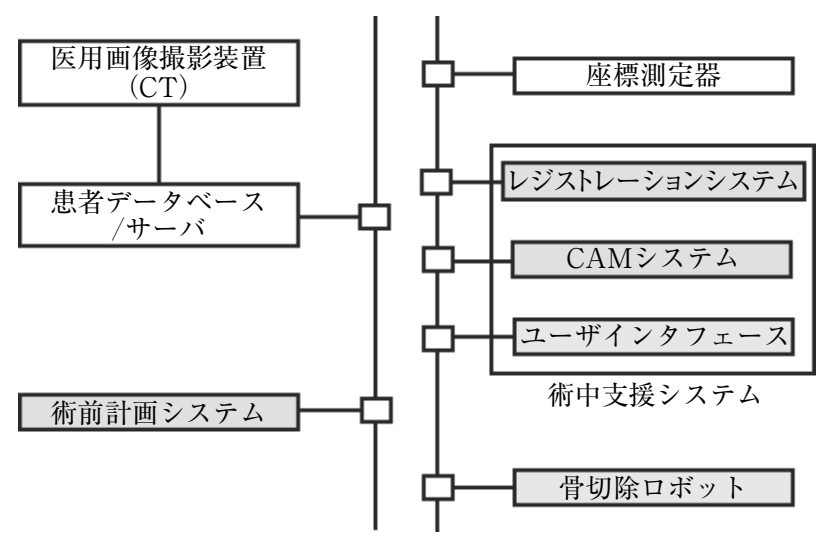

図 2 システム構成

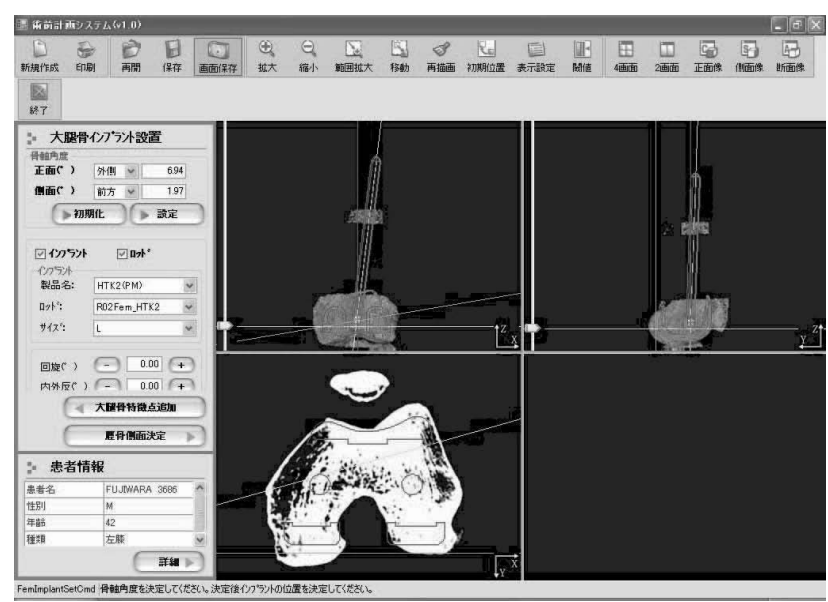

図 3 術前計画システム

人工関節置換術に打いては, 患部を止血して出血量を最 小限に抑えることで患者の負担を軽減する。この止血時間 は 1.5 時間程度が限界であるので，その時間以内で手術を 終了させる必要がある。

\section{5. システム構成}

人工膝関節置換術を対象として, 手術ロボットのシステ ム構成を図 2 に示す，本システムによって，X 線 CT 画 像をもとに 3 次元骨形状を把握してコンピュータ上で詳細 に人工関節設置位置を定義するとともに，そのデー夕をも とにロボットが高精度で骨切除を行うことができる。シス テムは大別して，手術計画を立案する術前計画システム， 手術の遂行を支援する術中支援システム，骨切除ロボット で構成される。

\section{1 術前計画システム}

従来の方法では, 人工関節の設置位置は 2 方向の $\mathrm{X}$ 線 レントゲン画像から決定される。このような方法では，患 者の撮影方向等の定義は曖昧であり，3 次元空間で詳細に 位置を定義するのは困難である。そこで，图３に示すよ うにCT 画像をもとに 3 次元骨形状を定義し, 人工関節設 置位置決定支援，および数值化を行う，処理時間短縮のた め, 3 次元骨形状は投影面補間型 APP (Average Pixel 


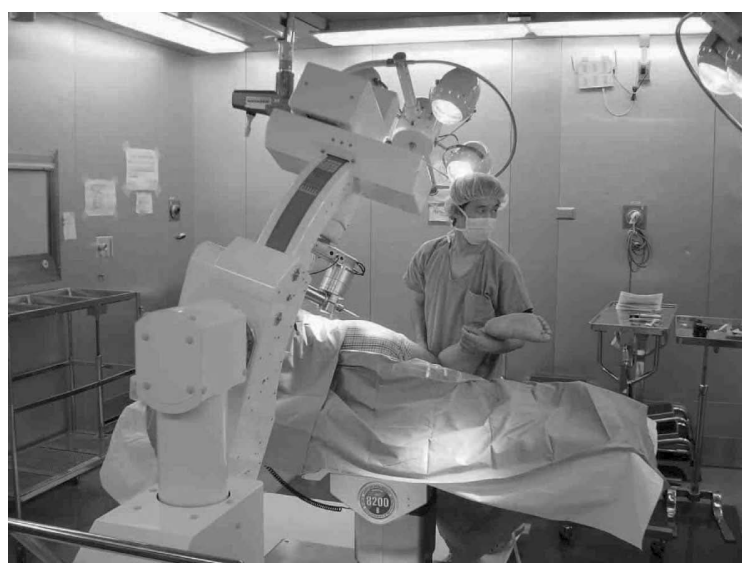

図4 多軸骨切除ロボット

Projection $)^{9)}$ を採用し, 術前計画終了後, 工具経路生成の ために CT 画像の CT 值を基準として 2 值化を行い, 骨形 状をボクセルデータとして出力する。 その他の主要機能と しては, 設置位置基準となる骨軸・荷重軸決定機能, ロボ ット座標系に切除平面座標系を変換するための特徵点抽出 機能を有する。

\section{2 術中支援システム}

術中支援システムはレジストレーションシステム, CAM システム，ユーザインタフェースから構成される. まず，レジストレーションシステムに扔いて，術前計画シ ステムで決定された骨特徵点と同点を座標測定器により計 測し, 最小二乗残差となる位置へ人工関節設置位置が定義 されている座標系を実空間上の骨切除位置に移動させる. CAM システムでは, 術前計画システムから出力された骨 形状を考慮した工具経路が生成されており, 切削対象の骨 以外の領域に工具が侵入しないように配慮されている。最 終的に，ロボットと骨位置を同時計測することで，CAM システムにより生成された工具経路をロボット座標系に変 換する。

これら一連の情報は, ユーザインタフェースで管理され る.ユーザインタフェースは, ウイザード形式を採用して 医師が操作に迷わないような設計になっている。必要な情 報はユーザインタフェースに提示され，医師が手術を行う 手を清潔域に保つため, フットペダルでの操作を可能とし ている.

\section{3 骨切除ロボット}

図 4 に骨切除ロボットを示す。骨切除を高精度かつ安 全に行うため, 下記のような特徵を有する。

（1）ロボットはCアーム構造としている。これにより, 医師の作業空間, および他の機器との共存を可能にしてい る。

(2) 先端に並進 3 軸（UVW 軸）に加えて回転 3 軸 （ $\mathrm{ABC}$ 軸）を設けている。回転 3 軸により工具に任意の姿 勢を定義させることが可能で, 骨切除の際の周囲組織との 干渉を回避することができる。

（3）各軸は直感的に動作が確認しやすい構造としてい
る。これにより，骨切除中のロボット動作の予測を容易に し, 患者・医師の安全を確保している.

(4) 先端の回転 3 軸は, 回転中心が 1 点に集中する構造 となっている。 これにより, 工具姿勢変更に際して変位が 発生せず, 安全かつ高精度に骨切除を遂行することができ る.

（5）スピンドル回転機構はスリーブでカバーし，骨切削 に寄与する工具先端部分のみ露出させている。 これによ り, 仮に工具軸と周囲組織が干渉しても組織損傷を防止で きる。

（6）さらに,アーム直下に上下軸 1 軸（Z 軸）を設け, 手術台の高さに合わせた工具アプローチを可能としてい る. 手術台との位置合わせのための軸を別途設けること で, 先端軸の稼動域を最小化することで，ロボット全体の 軽量化を達成し手術室の可搬性を向上させている.

（7）スピンドルを含めたロボットアーム先端の構造物を 清潔域と定義し, 脱着可能にしている。この機構により患 部に作用する部分を滅菌・洗浄を可能とするとともに, 緊 急時には清潔域の構造物を取り外し, 患部から構造物を退 避できるよう配虑されている。

実際の骨切除においては，Z軸にて手術台との高さ調整 後, アーム先端の回転 3 軸にて工具姿勢を定義し, UVW 軸の補間動作にて人工関節設置面を切除する。

\section{6. 適用結 果}

\section{1 切除精度}

図 5 (a) に示すように, 人体標本を用いた試験により 本システムの適用評価を実施した。 ボーンソーによる切除 では設置面間に最大 $4.5^{\circ}$ の角度誤差を生じていたが，図 5 （b）㧍よび表 1 に示す座標測定器による計測結果により 本システムでは最大 $1.8^{\circ} と な り$, 従来の手法と比較して誤 差を約 $1 / 3$ に低減することが可能となった，

\section{2 手術時間}

ロボットを適用した手術では脚の治具への固定, レジス トレーション等従来の手法にない工程がある。一方で, 従 来の一般的な手術で必要とされている人工関節設置位置を 決定するための各種治具の利用や図 1 のカッティングガイ ド等の設置が不要になったことで，手術時間は規定の 1.5 時間以内で可能であることを実証した.

\section{3 切削温度}

通常の金属切削と同様に，骨切削に扔いても被加工物の 温度上昇が起こる。骨組織は $50^{\circ} \mathrm{C}$ 以上の環境にさらされ ると壊死を引き起こすといわれている。 人工関節と骨を固 定する際には, 固定部分の人工関節表面を多孔構造とし, この多孔部分に骨を侵入させ投錨効果により固定力を獲得 するセメントレス法が多く用いられている。 したがって， 患者の早期回復のためには人工関節の固定部分と接する骨 組織を切除後も良好な状態で温存し, 早期の組織修復・成 長を促す必要がある。

そこで，エンドミル加工における温度上昇をサーモグラ 


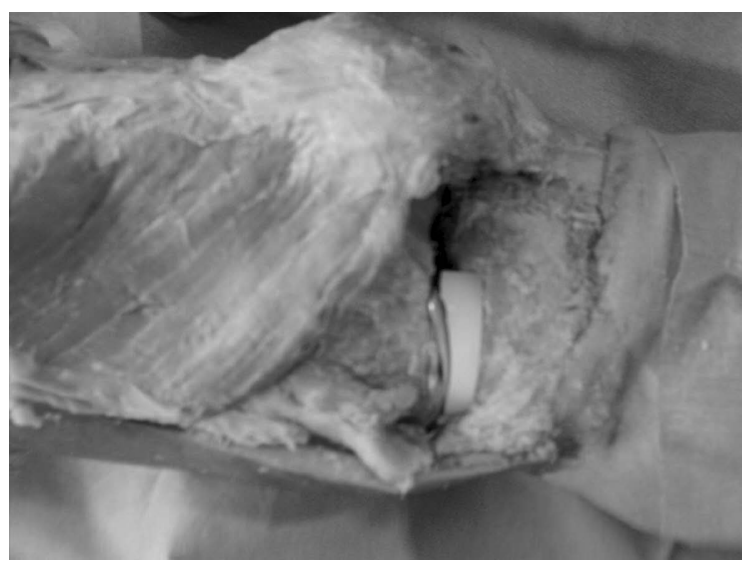

(a) 骨切除後

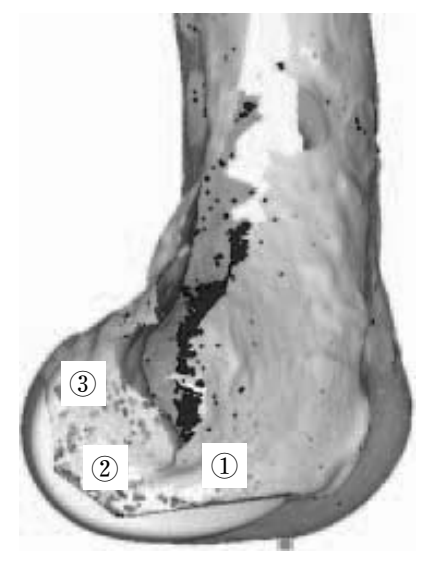

(b) 座標測定器計測結果

図 5 人体標本実験

表 1 設置面間の角度誤差

\begin{tabular}{c|c|c|c}
\hline 評価面 & 計画 $(\mathrm{deg})$ & 結果 $(\mathrm{deg})$ & 誤差 \\
\hline $1-2$ & 45.0 & 43.2 & 1.8 \\
$2-3$ & 52.0 & 52.8 & 0.8 \\
\hline
\end{tabular}

フィーにて計測した結果，生理食塩水による冷却で切削時

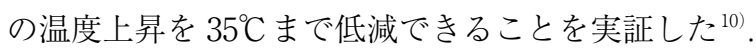

\section{7. 手術ロボットの技術展開}

ロボットによる手術では, 人間の手の大きさや視野の確 保といった制約がないため, エンドエフェクタ等の細径 化，CAD/CAM 技術の発展により低侵襲手術が可能であ ると考えられる。

また，人工関節製作技術とロボット手術を融合して $\mathrm{CAD} / \mathrm{CAM}$ データを一貫化することで, 患者の個々の体 格に合致したオーダーメイド医療の提供が実現できる。さ らに, 術後評価手法 ${ }^{11}$ を含めてシステム化し, 手術計画か
ら結果をデータベース化することで手術成績の累積的向上 が期待される。

\section{8. おわりに}

本稿では, 人工膝関節置換術を対象としたロボット技術 の適用に関する留意点について紹介した。本技術は，膝関 節のみならず股関節などの他関節置換術にも応用可能であ り, 今後急速に進行する高龄化社会において患者の QOL ならびにADLの向上に寄与できるものと考えている。ま た，本技術を基盤として整形外科一般，内臓系の手術にも 応用が可能である.

一方で, 手術ロボットの臨床応用には厚生労働省の認可 が必要であるが，現在認可に対する評価基準の策定が行わ れており，今後実用化に向けた指針が明確化されることに 期待している.

\section{参 考 文 献}

1) A. Mori, N. Tomita, T. Kaneeda, K. Nagata, H. Moriya, A. Osaka and K. Kuramoto: Wear Registance of UHMWPE Mixed with Vitamin E Supposing Lift-off in TKA, Transactions of the 48th Annual Meeting of the Orthopaedic Research Society, 27 (2002) 1041.

2) M. Neo, T. Nakamura, C. Ohtsuki, T. Kokubo and T. Yamamuro: Apatite Formation on Three Kinds of Bioactive Material at an Early Stage in Vivo: A Comparative Study by Transmission Electron Microscopy, J. Biomed. Mater. Res., 27, 8 (1993) 999.

3) T. Tsukeoka, M. Suzuki, C. Ohtsuki, A. Sugino, Y. Tsuneizumi, J. Miyagi, K. Kuramoto and H. Moriya : Mechanical and Histological Evaluation of a PMMA-based Bone Cement Modified with $\gamma^{-}$ methacryloxypropyltrimethoxysilane and Calcium Acetate, Biomaterials, 27 (2006) 3897-3903.

4) K.A. Krackow: The Technique of Total Knee Arthroplasty, St. Louis, C.V. Mosby, (1990).

5) L. Joskowicz, R. Taylor, et al. : Computer Integrated Revision Total Hip Replacement Surgery, Preliminary Report, MRCAS '95, (1995) 193-202.

6) G.S. Guthart and J.K. Salisbury: The Intuitive Telesurgery System: Overview and Application, Proceedings of the 2000 IEEE International Conference on Robotics and Automation, (2000) 618-621.

7) http://www.intusurg.com

8) M. Ghodoussi, S.E. Burtner and Y. Wang : Robotic Surgery-The Transatlantic Case, Proceedings of the 2002 IEEE International Conference on Robotics and Automation, (2002) 1882-1888.

9) M. Mitsuishi, S. Warisawa, F. Tajima, M. Suziki, K. Tanimoto and K. Kuramoto: Development of a 9 Axis Machine Tool for Bone Cutting, Annals of the CIRP, 52, 1 (2003) 323-328.

10）杉田直彦, 割澤伸一, 光石衛: 骨切削における硬度が切削性に 及ぼす影響掞よび切削温度の検討, 精密工学会学術講演会講演 論文集，2005S（2005）270.

11) S.A. Banks and W.A. Hodge: Accurate Measurement of Three Dimensional Knee Replacement Kinematics Using Single Plane Fluoroscopy, IEEE Trans. Biomed. Eng., 43, 6 (1996) 638. 